\title{
Locating financial incentives among diverse motivations for long-term private land conservation
}

\author{
Matthew J. Selinske $^{1,2}$, Benjamin Cooke ${ }^{3}$, Nooshin Torabi ${ }^{1}$, Mathew J. Hardy ${ }^{1,2}$, Andrew T. Knight ${ }^{2,4,5,6}$ and Sarah A. Bekessy $^{1,2}$
}

\begin{abstract}
A variety of policy instruments are used to promote the conservation of biodiversity on private land. These instruments are often employed in unison to encourage land stewardship beneficial for biodiversity across a broad range of program types, but questions remain about which instruments are the appropriate tools when seeking long-term change to land-management practice. Drawing on three case studies, two in Australia and one in South Africa, spanning various program types - a biodiverse carbon planting scheme, a covenanting program, and a voluntary stewardship program - we investigate the importance of financial incentives and other mechanisms from the landholder's perspective. From participant interviews we find that landholders have preconceived notions of stewardship ethics. Motivations to enroll into a private land conservation program are not necessarily what drives ongoing participation, and continued delivery of multiple mechanisms will likely ensure long-term landholder engagement. Financial incentives are beneficial in lowering uptake costs to landholders but building landholder capacity, management assistance, linking participants to a network of conservation landholders, and recognition of conservation efforts may be more successful in fostering long-term biodiversity stewardship. Furthermore, we argue that diverse, multiple instrument approaches are needed to provide the flexibility required for dynamic, adaptive policy responses. We raise a number of key considerations for conservation organizations regarding the appropriate mix of financial and nonfinancial components of their programs to address long-term conservation objectives.
\end{abstract}

Key Words: biodiversity; covenant; easement; farmer engagement; market-based instrument; policy mix; program design; reverse auction; stewardship

\section{INTRODUCTION}

A primary aim of private land conservation (PLC) programs is to motivate landholders toward preservation, active management, restoration, and sustainable utilization of private lands to support biodiversity and landscape conservation (Stern 2006). Conserving biodiversity on private lands depends not only on protection but also long-term management (Naidoo et al. 2006). As such PLC programs must not only consider initial landholder uptake but also how the program fosters and sustains landholder stewardship through time (Greiner and Gregg 2011). Land stewardship, which has been documented among rural landholders for decades (Leopold 1949), is the set of ideas and practices that landholders use to manage their properties for long-term public and private benefits (Worrell and Appleby 2000), capturing the desire to conserve biodiversity as well as to act as custodian of production landscapes (Gill et al. 2010). Encapsulated within stewardship is the notion of legacy: an aspiration to improve or maintain the condition of the land for the benefit of future landholders. The long-term stewardship motives of landholders align with a range of different instruments for PLC, including management assistance, permanent protection, recognition, social learning, and financial incentives (Gunningham and Young 1997).

The instruments supporting PLC are often used in conjunction, providing different mechanisms to increase program participation among landholders, while meeting multiple objectives. Optimally, a mix of instruments will be implemented by different organizations at multiple governance levels within the same conservation and geographic space, acting in concert to protect biodiversity on private lands (Young and Gunningham 1996). Because the social-ecological settings of private lands are complex, programs must accommodate their inherent dynamism by carefully selecting and employing a complementary mix of instruments (Stirling 2010).

Financial incentives compensate landholders for the costs associated with land management or opportunity costs, reducing impediments to program uptake (Pannell and Wilkinson 2009). In a variety of economic contexts, the use of financial incentives operates under the assumption that people will shift more readily and effectively toward proenvironmental behavior when a fiscal inducement is offered (Farrier 1995). However, while financial incentives are at times instrumental to securing a PLC agreement (Moon and Cocklin 2011) and short-term shifts in land management have been documented (Kay et al. 2013), it remains unclear what specific role financial incentives play in engendering a long-term stewardship perspective, given the complex array of nonfinancial motivations that constitute stewardship (Reimer et al. 2012).

Currently, financial incentives are applied in various ways to promote proconservation land management. These include direct and indirect payments or reimbursements, aimed at inducing positive, or preventing negative, behavior (Pannell 2008). Financial incentives are commonly used to remove perceived barriers to landholder participation, leveraging conservation action from individuals or communities lacking the interest or financial means to conserve or restore their land (van Putten et al. 2011, Race and Curtis 2013).

\footnotetext{
${ }^{1}$ Interdisciplinary Conservation Science Research Group, School of Global, Urban and Social Studies, RMIT University, Melbourne, Australia, ${ }^{2}$ ARC Centre of Excellence for Environmental Decisions, The University of Queensland, Australia, ${ }^{3}$ Centre for Urban Research, School of Global, Urban and Social Studies, RMIT University, Melbourne Australia, ${ }^{4}$ Department of Life Sciences, Imperial College London, ${ }^{5}$ Department of Botany, Nelson Mandela Metropolitan University, ${ }^{6}$ The Silwood Group, London, UK
} 
Table 1. Program attributes and study methods.

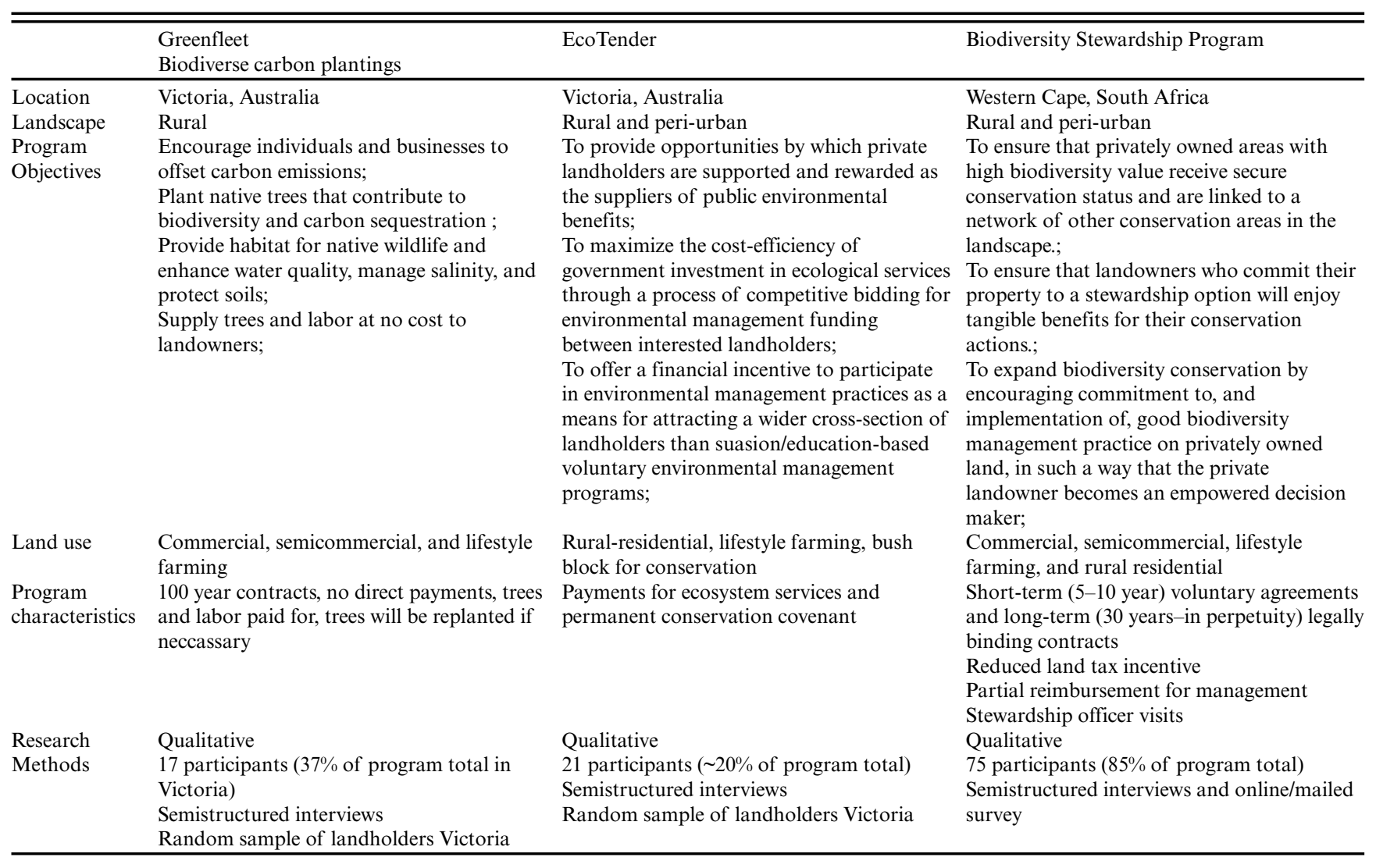

Using insights from three PLC programs in Australia and South Africa that represent different types of financial incentives, i.e., carbon offset, reverse auction, and rates rebates (Table 1), we sought to explore how different types of financial incentives interact with the diversity of landholder's motivations to participate in PLC and how they contribute to sustaining longterm commitment to PLC. In our investigation we highlight three key issues requiring critical attention if financial incentives are to be explicitly designed to improve PLC program effectiveness: (1) engaging landholders' existing notions of stewardship, (2) applying financial incentives in a way that is attentive to securing long-term benefits, and (3) decentering financial incentives as the core mechanism in a broader mix of instruments. We then draw from these insights to argue that uncritical use of financial incentives risks disregarding the complexity of social-ecological systems ( $\mathrm{Li}$ and $\mathrm{Li}$ 2012) including the diversity of participant motivations, expectations, and experiences (Moon and Cocklin 2011, Selinske et al. 2015). We also suggest that the positioning of financial incentives as the dominant approach potentially compromises the effectiveness of PLC programs, particularly through their lack of capacity to respond to the complexity, diversity, and dynamism of social-ecological systems (Muradian et al. 2013).

\section{Reviewing the challenges for implementing financial incentives}

Financial incentives have proven to be an attractive proposition for conservation organizations because they (a) increase participation rates (Ernst and Wallace 2008); (b) allocate funding in a quantifiable and verifiable way (Robins and Kanowski 2011); and (c) have the potential to deliver immediate outcomes, e.g., prevention of vegetation clearing (Binney et al. 2010). The use of financial incentives accords with the view that landholders should be compensated for the lost opportunities to pursue land uses that compromise nature, in their provision of ecological benefits for the public good (Morrisette 2001). Perhaps most significantly, the advertised benefits of financial incentives are frequently set against the perceived failure or limitations of other approaches to PLC, namely regulatory instruments and suasion efforts (Cocklin et al. 2007, Whitten et al. 2013). In this sense, the rise of financial incentives fits within a neoliberal framework for PLC and environmental policy more generally (e.g., Robertson 2004, Higgins et al. 2014).

To date, the development and evolution of financial incentives has centered on the "needs of the [funding] provider" (Sorice and Donlan 2015:788), with particular emphasis on reducing the implementation and transaction costs of PLC programs. This approach risks utilizing financial incentives because of their perceived alignment with existing governance structures or mentalities, rather than their suitability to a specific on the ground context (Higgins et al. 2012, Cooke and Moon 2015). Accounting for context in program design is vital (Young et al. 1996); if financial incentives are applied without careful consideration, it is possible that the investment by conservation organizations in fostering stewardship may be jeopardized. 
Table 2. Case study questions.

\begin{tabular}{|c|c|c|}
\hline EcoTender & Greenfleet & Biodiversity Stewardship Program \\
\hline $\begin{array}{l}\text { How did you come to decide that EcoTender } \\
\text { would fit with your conservation efforts? }\end{array}$ & What were your motivations for participation? & $\begin{array}{l}\text { Can you please list your reasons for entering the } \\
\text { biodiversity stewardship programme? }\end{array}$ \\
\hline $\begin{array}{l}\text { What do you see as the major benefits of the } \\
\text { EcoTender program? }\end{array}$ & $\begin{array}{l}\text { How do you describe the benefits of participating } \\
\text { in Greenfleet? }\end{array}$ & $\begin{array}{l}\text { How do you feel you benefit from being involved } \\
\text { in the biodiversity stewardship programme? }\end{array}$ \\
\hline $\begin{array}{l}\text { What is one aspect of the program you would } \\
\text { change if you could that you think would have } \\
\text { enhanced your experience of it? }\end{array}$ & $\begin{array}{l}\text { Are you satisfied with your current agreement } \\
\text { with Greenfleet? }\end{array}$ & $\begin{array}{l}\text { Do you have any suggestions on how to improve } \\
\text { the biodiversity stewardship programme? }\end{array}$ \\
\hline $\begin{array}{l}\text { What activities do you think you } \\
\text { will continue when the program concludes? }\end{array}$ & $\begin{array}{l}\text { How did you find managing/integrating new } \\
\text { plantings with your usual business? }\end{array}$ & What are your long-term goals for your land? \\
\hline
\end{tabular}

The fixed-term nature of some financial incentives highlights the danger of a mismatch between the length of time the PLC program runs and the time required to achieve on-ground conservation outcomes. Financial incentives can fundamentally change a landholder's willingness to contribute to conservation activities, arguably a main benefit for governments implementing PLC programs (Rode et al. 2015). Direct payments can potentially increase the cost of conservation over time as landholders come to expect payments, seeing them as an entitlement, or creating dependencies, leading to questions over what happens if or when the incentives cease (Elmendorf 2003). Organizations must also account for both the immediate expenditure associated with financial incentives and the subsequent uncertainty of their investment for producing lasting biodiversity outcomes where political, economic, and climatic conditions may change, potentially compromising a program's ecological, social, and/or cost-effectiveness (Rissman 2011, Mendham et al. 2012). Moreover, market-based instruments (MBI) and similar direct financial incentives that prominently feature in the financial aspect of the program may lack the dynamism required to cover rising opportunity costs, the need for social learning and knowledge sharing in a changeable social-ecological setting, or guaranteed funding for the long timelines suitable to landscape scale restoration and protection (Swart et al. 2003). In the face of these issues, clear questions remain about whether financial incentives are the appropriate tool when seeking long-term change to land-management practice.

\section{METHODS}

\section{Introduction to empirical case studies from Australia and South Africa}

To illustrate the complex social-ecological interactions around PLC into which financial incentives are being introduced, we draw from empirical research in Australia and South Africa. The qualitative research that we engage with offers deep insights that clearly expose the need for diverse approaches to PLC. Exploring the detail and nuance of conservation efforts as they play out on the ground through interviews and participant observation provides a counterbalance to existing assumptions and predictions for how financial incentives and other instruments might operate.

Each case is defined by the implementation of a financial incentive program in a given geographical area. Case study research was pursued in all three instances because it encourages an in-depth exploration and analysis of phenomena in a real-life context (Stake 1995). The commonality between cases in the way they are defined makes a combined approach to analysis appropriate in this instance. Additionally, questions asked by researchers of each case study were similar in nature (Table 2). During a one-day workshop we discussed each case study in detail identifying similar objectives of the research and common themes discovered in the results (George and Bennett 2005).

A key limitation of our research is that it is based on three case studies sharing similar private property rights characteristics, which may constrain its applicability beyond similar contexts. We are not seeking to generalize from our cases, but to provide examples that illustrate the range and complexity of stewardship motivations to which financial incentives must be attentive.

\section{Case studies}

Greenfleet

Greenfleet is a not-for-profit organization collaborating with landholders to plant multiple species of native trees on private lands throughout Australia to offset the greenhouse gas emissions of businesses and individuals. Although landholders do not receive direct financial incentives for participating, Greenfleet agrees to cover the costs of restoration, with landholders then obliged to manage the revegetated land for 100 years. Landholders were recruited through a posted invitation facilitated by Greenfleet. Interviews took place between January and September 2013 with 17 private landholders. In-depth, semistructured interviews were used to obtain comprehensive data about peoples' experiences, perceptions, and opinions. Interviews took one to two hours and included walking or driving around participants' properties with them as the interview progressed. This enabled the interviewers to gain a grounded understanding of the landholder's experiences with their carbon plantings. The interview questions asked pertained to landholder drivers to participate in a carbon offset, land management challenges, and critiques of the program.

Interviews were tape-recorded and transcribed verbatim. Data analysis was informed by a thematic approach that helps to discover and present the patterns found in the interviews (Braun and Clarke 2006, Saldaña 2009). Interview materials were coded line by line using an open coding technique in NVivo 10 qualitative analysis software (QSR International 2012, http://www. qsrinternational.com).

\section{EcoTender}

In this study, participants in the Victorian EcoTender Program (from eastern Victoria) were interviewed on their properties. EcoTender is a reverse auction tender program, run by the State 
of Victoria, requiring landholders to bid for funds to complete agreed conservation works on their land. The conservation agency then allocates funds to the bids that represent the best return on investment. Once landholders are selected to participate, the program contract runs for five years.

Landholders were recruited by an e-mail sent to all landholders in the case study region who had been successful with their EcoTender bid. The e-mail contained a summary of the research objectives and central research questions of interest (captured in Table 2), with interested landholders contacting the researcher to participate. Property visits took place in 2010 (seven interviews) and 2016 (15 interviews) as part of an ongoing study of PLC program participation in Victoria. In-depth, semistructured interviews were held with landholders, followed by the interviewer walking the participants' property with them (in a similar manner to the Greenfleet study). The intention of the interviewer was to acknowledge that the landscape serves as a repository of memory when people have a strong attachment to place, which allowed participant perspectives on program participation to be linked closely with on-ground activities (Strang 2010). Research questions focused on how landholders' environmental management practices emerged and developed over time, and the way PLC programs shaped, or were shaped by, landholder conservation motivations and practice. Interviews and notes from the property walks were transcribed and coded using an open thematic coding approach, which groups together passages with common ideas and perspectives to build a substantive thematic structure around a shared idea (Saldaña 2009). The NVivo software package was used to facilitate the coding. Emergent themes were discussed in detail and presented to colleagues for critical reflection and discussion as the research progressed.

\section{Biodiversity Stewardship Program}

Since 2003, South Africa has worked toward meeting national protected area and critical biodiversity targets through the Biodiversity Stewardship Program (BSP), a PLC initiative. Although coordinated at the national level, the BSP is implemented at the provincial level. This research, conducted over nine months from July 2013 through to March 2014, assessed the motivations of landholders participating in the Western Cape province's BSP, how these motivations and program implementation generated satisfaction or dissatisfaction with the program, and predicted the likelihood the landholder would remain in the BSP after a contract ended. These three factors were measured qualitatively through semistructured interviews and by online or mailed surveys.

CapeNature, the Western Cape's parastatal conservation agency, provided a list of all BSP landholders ( 88 households) who were then contacted by e-mail or phone. Initially, all landholders were sent an e-mail or a mailed survey (Dillman et al. 2009) of which 35 landholders responded. An additional 40 were interviewed in person using the same protocol as the mailed surveys. On average, interviews took one to two hours to complete. If convenient for the landholder, interviews took place while touring their land enrolled in the BSP. Questions focused on the landholder's relationship with the land and the BSP, motivations to participate in PLC, how the BSP could be improved, and land management goals. Responses were coded based on themes identified by a priori understanding of the program or those that emerged during analysis (Kitchin and Tate 2000, Braun and Clarke 2006). Coding themes centered on identifying landholder motivations to participate in the BSP, satisfaction with the program, and commitment to management objectives and remaining in the program. Recurrent themes were identified and interrogated with two coresearchers as part of the coding process. Additional insights into the BSP based on quantitative methodology were reported in Selinske et al. 2015.

\section{RESULTS AND DISCUSSION}

We synthesize the findings from our individual case studies, including demographics (Table 3), and draw out three themes in the data that relate to the use of financial incentives in PLC.

\section{The need to engage with existing stewardship ethic}

Although the reverse auction EcoTender program seeks to attract landholders by offering payments for the delivery of ecosystem services, some participants used the program as a means for placing an in perpetuity conservation covenant on their land, a motivation that aligns with legacy preservation that extends beyond the duration of their own land tenure. For example, 38\% of the Victorian landholders surveyed submitted EcoTender bids upon discovering the program offered a permanent protection agreement. These landholders were previously unsuccessful in securing a covenant through other conservation organizations, having been told that their patches of mixed remnant and revegetated forest were not considered of significant ecological value. As a result, $20 \%$ of landholders who did not have existing covenants deliberately placed a low bid to increase their likelihood of getting the covenant, even though that meant the money they received only covered between a third and half of their land management costs:

\section{Because [the restoration is] something I would have done anyway but I think the real bait for me was the covenant. If I did all this [work] and after I've gone somebody buys the land and knocks it all over, what's the point [of restoration]?}

One landholder saw EcoTender as an alternative way to realize an existing desire to protect the landscape from encroaching local development. The attraction of the scheme was that it "had teeth" in terms of regulatory controls that helped to see "all this [work]" preserved. Although landholders implemented this program creatively to align with their stewardship objectives, the hybridity of the program, where multiple mechanisms are combined into the one initiative, appealed to a diversity of landholder stewardship aspirations (Gunningham and Young 1997).

Another landholder was enthusiastic about the EcoTender scheme for similar reasons: "I wanted to protect it into the future for the environments who can't protect themselves and for all the many people who have come and helped [with the restoration effort]." Here, the motivation was to protect restoration efforts for their habitat value, but also because the vegetation embodied the efforts of friends and neighbors who had assisted. Ensuring a future owner could not undo these efforts was critical, suggesting the importance on securing long-term conservation benefits as part of landholders' motivations. These sentiments are commonly expressed by landholders who have sought out covenants or easements to protect their land and/or conservation efforts (Harrington et al. 2006, Lai and Kreuter 2012). These examples 
Table 3. Socio-demographics of program participants.

\begin{tabular}{|c|c|c|c|c|c|c|}
\hline & \multicolumn{2}{|c|}{ Age } & \multicolumn{2}{|c|}{$\begin{array}{c}\text { Term of } \\
\text { ownership }\end{array}$} & \multirow{2}{*}{$\begin{array}{l}\text { Majority of income generated from } \\
\text { property (productive land use) }\end{array}$} & \multirow{2}{*}{$\begin{array}{l}\text { Livelihoods/land use } \\
\text { Commercial/ } \\
\text { semicommercial: } 59.0 \% \\
\text { Lifestyle/hobby farm: } 41.0 \%\end{array}$} \\
\hline Green Fleet & $\begin{array}{l}25-39 \\
40-54 \\
55-69 \\
70-99\end{array}$ & $\begin{array}{l}18.0 \% \\
41.0 \% \\
29.0 \% \\
12.0 \%\end{array}$ & $\begin{array}{l}<5 \text { years } \\
5-20 \text { years } \\
>20 \text { years }\end{array}$ & $\begin{array}{l}12.0 \% \\
53.0 \% \\
35.0 \%\end{array}$ & & \\
\hline Biodiversity & $30-39$ & $5.70 \%$ & $<5$ years & $6.30 \%$ & $46 \%$ of participants generated & Commercial/ \\
\hline Stewardship & $40-49$ & $17.1 \%$ & $5-20$ years & $62.5 \%$ & majority of income from property & semicommercial: $63.0 \%$ \\
\hline Program & $\begin{array}{l}50-59 \\
60-69 \\
70-99\end{array}$ & $\begin{array}{l}20.0 \% \\
40.0 \% \\
17.1 \%\end{array}$ & $\begin{array}{l}>20 \text { years } \\
2 \text { or more } \\
\text { generations }\end{array}$ & $\begin{array}{l}12.5 \% \\
18.6 \%\end{array}$ & & Lifestyle/hobby farm: $27.0 \%$ \\
\hline EcoTender & $\begin{array}{l}30-39 \\
40-49 \\
50-59 \\
60-69 \\
70-79\end{array}$ & $\begin{array}{l}10.0 \% \\
25.0 \% \\
35.0 \% \\
21.0 \% \\
10.0 \%\end{array}$ & $\begin{array}{l}<5 \text { years } \\
5-15 \text { years } \\
>15 \text { years }\end{array}$ & $\begin{array}{l}10.0 \% \\
69.0 \% \\
21.0 \%\end{array}$ & $\begin{array}{l}24 \% \text { of participants generated the } \\
\text { majority of their income from } \\
\text { property }\end{array}$ & $\begin{array}{l}\text { Commercial/ } \\
\text { semicommercial: } 30.0 \% \\
\text { Lifestyle/hobby farm: } 70.0 \%\end{array}$ \\
\hline
\end{tabular}

reveal that financial incentives were often secondary considerations for landholders compared with other aspects of the program, despite being the centerpiece of EcoTender program design.

The creative interpretation of incentive-based programs offers insights into the complex, diverse, and unanticipated ways in which an existing stewardship ethic can interact with a financial incentive. Although landholders generally found ways to accommodate their conservation motives, the EcoTender example suggests that the financial incentives in question could focus more intently on connecting with existing and ongoing landholder stewardship efforts, rather than a finite policy intervention that is detached from a social and ecological context. By doing more to recognize existing stewardship, financial incentives can be designed and implemented in ways that better accommodate nonfinancial motives for conservation, rather than some landholders having to co-opt programs to meet their needs.

In the Greenfleet case study, land restoration was a strong driver for landholders to consider participation in the scheme. Reflecting a stewardship ethic, $89 \%$ of landholders were motivated by the idea of restoring land to provide more suitable habitat for native fauna. As one participant noted: "We just...wanted to rehabilitate the land I suppose, so we wanted to bring back what would have been here with the habitat to the local fauna." Additionally, landholders tended to take an eco-centric approach toward their land: as one landholder expressed "So it's just we kind of feel like that we're doing something for the health of the land and giving something back instead of just taking stuff away from it."

Similarly, with BSP participants, although a few landholders were previously uninterested in conservation prior to learning about the program, for many an existing stewardship ethic was already in place. The protection of land in perpetuity was used to describe $45 \%$ of landholder's motivations often in conjunction with "safeguarding nature for future generations." Others $(22 \%)$ discussed a moral obligation to protect nature or for one "divine purpose." Landholders in all three case studies expressed a belief that they were part of the biotic community that exists on their property, a view very much in line with Leopold's stewardship ethic (Leopold 1949). Moral aspects of caring for land through stewardship can be powerful drivers of program participation, irrespective of what the main objective and intention of the program might be.

\section{Securing participation and long-term collaboration}

A challenge to PLC programs and their long-term effectiveness is the interplay between different types of incentives and how they work to retain landholders. Effective PLC programs cater for the multiple, diverse motivations held by individuals and groups of landholders across a landscape (Young et al. 1996, Knight et al. 2010, Armsworth et al. 2012). However, programs often must continue to incentivize landholders postenrolment to ensure they remain in a program, manage their property for biodiversity gains, and comply with agreed management practices (Sorice et al. 2013). As in other environmental programming, this can be a secondary consideration; once knowledge is gained, attitudes are shifted, or adoption and uptake is in place, it is measured as an output or outcome with little consideration toward longer term impact (Wilson and Hart 2001).

Research in conservation volunteerism suggests that the initial motivations for volunteering are unrelated to the attributes of the program that drive continued participation (Ryan et al. 2001, Asah and Blahna 2013). The evolution of motivations reflects a similar process of participation and engagement among PLC landholders. Within the BSP the motivations that landholders stated for initially enrolling in the program were often not the same motivations that contributed to their overall program satisfaction or that engendered long-term commitment to the program. Landholders were motivated by their own conservation goals to adopt the program; $98 \%$ of landholders expressed that the impetus to participate in the BSP was to protect and properly manage the landscape and protect the species on their land. Enrollment for nearly $30 \%$ of participants was facilitated by a land tax rate reduction, although it was clearly expressed that this was not central to participating, just "a sweetener." In contrast, continued participation in the BSP was linked by $74 \%$ of landholders to the efficacy of land management assistance and training, the quality of the landholder's relationship with the 
management agency, and the frequency of visits by a stewardship officer. Of those responding negatively the landholders felt they "had kept up their end of the bargain" but were neglected by the BSP. These results are supported by previous BSP work (Cumming 2007, Pasquini et al. 2010), conservation psychology research into motivations (De Young 2000), and factors driving satisfaction (Stroman and Kreuter 2015).

Similarly, participants in the Greenfleet scheme were initially drawn to the program by access to low-cost tree planting and assistance in land restoration. Sometimes this linked to underlying motivations, as one participant noted, "Our dream was always not to farm the land but to plant it back up as bush." However, through interviews it became clear that motivation had shifted with participation, and the partnership with Greenfleet staff and associated capacity building was an important component of ongoing program satisfaction. Landholders' capitalized on Greenfleet's regular monitoring of trees to engage foresters for management guidance and support. Of the landholders in this study, 94\% emphasized the role of the extension officer (foresters) in facilitating landholders' access to information and linked this continued engagement to the increased likelihood of long-term sustained outcomes. As a landholder noted "It's the knowledge and the connections that Greenfleet have got that I don't have to worry about."

In the case of EcoTender, part of ongoing participant satisfaction appeared to be linked not with the initial interaction with program staff or the securement of a covenant, but rather with other participants. The desire for social networking opportunities through EcoTender was notable, with $60 \%$ of EcoTender participants wanting some form of engagement with other landholders. However, because of the competitive design of the auction bidding process, there was no formal way to interact with one another. As has been noted with MBIs designed in this fashion, the use of a competitive funding instrument can constrain collaboration on land management between landholders (Cooke and Moon 2015). As one participant noted, "it would be great if we did have...some sort of networking opportunity. It would be nice to see how successful other participants have been, whether they ran into problems... ." Being able to discuss the program with fellow participants can help with knowledge sharing and with advice on implementing the scheme effectively (Riley 2006).

There is a risk that management organizations can prioritize PLC program outputs over long-term conservation outcomes that are beyond the life of any given program (Wilson and Hart 2001). The diversity and dynamism of landholder motivations and satisfaction demands that financial incentives complement and augment, other instruments such as capacity building, stewardship officer visits, establishment of social networks, and recognition of landholder efforts that support nonfinancial motivations and engender long-term commitment. Financial incentives facilitate a landholder's intention by removing barriers and providing opportunities for participation. However, effective ongoing conservation management requires more than increasing program participation or removing barriers to participation.

Sustaining landholder involvement necessitates continued behavioral reinforcement (Stern 2006). This can be achieved by building collaborative partnerships between landholders and conservation organizations (Wondolleck and Yaffee 2000, Cooke et al. 2012), development of landholder networks, continued visibility through auditing, and efforts toward comanagement through land management assistance. For example, a collaborative conservation ethic may mean rethinking the design of MBIs like EcoTender, to enable formal landholder networks than can extend beyond a conservation payment contract. This collaborative process reinforces both landholders' self-efficacy (Bandura 1977) and proenvironmental social norms among participating landholders (Knight et al. 2010).

\section{Long-term stewardship is best supported by a diverse offering of mechanisms}

Our case studies highlight that the relationship between financial incentives and on-ground conservation outcomes is likely to be complex, and could be nonlinear, especially given the uncertainty over ongoing management postcontract. There is little doubt that financial incentives support transitions into PLC programs by covering opportunity costs and investments, particularly for landholders financially dependent on their land (Burns et al. 2016). However, we contend they are not suitable as the backbone of a PLC strategy, particularly for organizations seeking longterm outcomes. Indeed there are substantial risks in relying too heavily on PLC programs that are designed with a financial incentive as their centerpiece. Here we detail how a diverse offering of mechanisms can best develop and enhance stewardship, in particular stewardship extension support.

The BSP illustrates a balanced mix of mechanisms that successfully entices landholders by providing multiple pathways into the program, and engages them in the long term with continued stewardship support. The program can secure valued nature across four tiers of increasing protection, supported by increasing degrees of financial and management support, each offering commitment options to match landholder needs. Landholders enrolled in the BSP receive nonfinancial incentives from government organizations including land management advice, invasive plant species management support, and fire management assistance delivered through an extension officer. Landholder buy-in of these activities is compulsory, increasing co-ownership of land restoration and materials, e.g., fencing or herbicide. Landholder achievements are also recognized through an annual landholder awards night, and signage designating the land as part of the BSP. Landholders use the status of their stewardship lands as a form of accreditation to market ecotourism business and "green" products, e.g., wine, fruit, flowers. Increasing landholder commitment through the BSP by increasing the term and conditions of the contract is matched by an increasing amount of support from the conservation authority.

Lands with the highest conservation value and those with titledeed restrictions of 30 years or higher receive property tax exemption (Cumming et al. 2015). This indirect financial incentive is intended to mitigate the effect of removing land from agricultural status, which in South Africa is taxed at a lower rate than that of conservation status. Audits of the participants are conducted yearly, complementing the mix of incentives with an enforcement instrument. The BSP generated a sense of partnership by comanaging lands with landholders. Over a third of BSP participants offered similar sentiments to the landholder who expected "collaboration on joint projects [on the stewardship land]...there is much we [the BSP and the landholder] can do together." 
By providing a variety of mechanisms, i.e., tax incentive, information, property-rights instrument, enforcement, accreditation, and awards, the BSP achieves a standard that other programs in both developing and developed countries could emulate to increase uptake in a heterogeneous population of landholders and maintain long-term stewardship among participants. During the interviews the full range of instruments offered by BSP were described as beneficial, but some such as land and invasive plant management assistance came up more frequently with $63 \%$ of participants remarking on their importance. As a landholder remarked, "The benefits that I have enjoyed so far, funding [for invasive clearing], technical assistance, managing, as well as labor for clearing, have been invaluable to our farm." Our analysis demonstrated that stewardship extension officer support in particular had an outsized influence on BSP satisfaction with $74 \%$ of program landholders discussing the importance of interaction with a stewardship officer. This is similar to findings from our other case studies, which were not established with the intention of providing landholders with support from a stewardship officer.

Of the surveyed EcoTender participants, 35\% reported that the site visit by an extension officer to assess their reverse auction tender bid as one of the highlights of the program. Given the paucity of extension opportunities available to landholders, participants used this visit as a chance to ask important questions about land management, species identification, and landscape change. Knowledge-sharing and social interaction with an extension officer or a social network of landholders can motivate landholders to sustain long-term conservation efforts. Additionally, landholders in the Greenfleet program stated that having foresters visiting their properties to monitor carbon is an important element of the program: "they [Greenfleet's foresters] know their stuff, they know when to plant, they've been fantastic."

In both of the Australian examples, the advice and assistance provided to landholders through property visits from extension officers was important, but happened informally. Integrating these opportunities for enhancing landholder knowledge and capacity more formally as a program instrument may assist in the continuation of land management practices after a program concludes (EcoTender) or when property visits are infrequent (Greenfleet). This is especially important when program involvement presents new land management challenges that participants have not previously encountered.

\section{CONCLUSION}

If PLC programs are to deliver conservation benefits on private land that are sustained and supported by landholders, the instruments utilized need to be positioned within an overarching strategy that recognizes a dynamic social-ecological context (Gunningham and Young 1997). Financially incentivizing enrolment can be a useful tool to draw landholders into a PLC program, but landholders' ongoing participation in programs is driven by a variety of factors that are not necessarily related to economic considerations (Selinske et al. 2015).

Our case study results reinforce the need for flexible and diverse approaches to conservation policy that emphasize a suite of policy mechanisms. There is substantial evidence from our case studies and existing research that financial incentives are not well suited to being the foundation upon which PLC policy and programs should be built. Policy makers need to be open to the ways in which landholders' "practical and emotional attachments" (Trigger et al. 2010:1070) to their landscapes manifest through their stewardship ethic and connect with, reinterpret, or resist program objectives. Ideally, to secure conservation benefits on private land, program design would consider what is required to foster stewardship over the long term.

We suggest that recognizing social-ecological complexity and responding to the dynamism and uncertainty that this entails (which makes the rigidity of some financial incentive programs less attractive) needs to be considered upfront when designing PLC policy. To enhance a landholder's ability to respond to change, we need cooperation and critical reflection among and between the different actors in PLC program design and implementation. Financial incentives that do not foster collaboration and ongoing stewardship may be problematic in the long-term, especially in the face of indefinite political support for conservation initiatives. As we have argued, an approach to PLC that centers on the context of implementation and responds to a diverse range of landholder stewardship motivations benefits both landholders and conservation organizations, enhancing the potential for long-term ecological benefits.

Responses to this article can be read online at: http://www.ecologyandsociety.org/issues/responses. $\mathrm{php} / 9148$

\section{Acknowledgments:}

We would like to thank the editors and the three anonymous reviewers for their helpful insights and comments. Support from the School of Global, Urban and Social Studies at RMIT University, Melbourne, Australia, the Department of Life Sciences at Imperial College, London, the Australian Research Council's Centre of Excellence in Environmental Decisions (CEED) at The University of Queensland, Australia is gratefully acknowledged. SB and MS were also funded by an ARC Future Fellowship and NT was supported by the National Environment Research Programme Threatened Species Recovery Hub.

\section{LITERATURE CITED}

Armsworth, P. R., S. Acs, M. Dallimer, K. J. Gaston, N. Hanley, and P. Wilson. 2012. The cost of policy simplification in conservation incentive programs. Ecology Letters 15(5):406-414. http://dx.doi.org/10.1111/j.1461-0248.2012.01747.x

Asah, S. T., and D. J. Blahna. 2013. Practical implications of understanding the influence of motivations on commitment to voluntary urban conservation stewardship. Conservation Biology 27(4):866-875. http://dx.doi.org/10.1111/cobi.12058

Bandura, A. 1977. Self-efficacy: toward a unifying theory of behavioral change. Psychological Review 84(2):191-215. http://dx. doi.org/10.1037/0033-295X.84.2.191

Binney, J., K. Whiteoak, and G. Tunny. 2010. Review of the environmental stewardship program. Marsden Jacob Associates, Camberwell, Victoria, Australia. 
Braun, V., and V. Clarke. 2006. Using thematic analysis in psychology. Qualitative Research in Psychology 3(2):77-101. http://dx.doi.org/10.1191/1478088706qp063oa

Burns, E., C. Zammit, S. Attwood, and D. Lindenmayer. 2016. The environmental stewardship program: lessons on creating long-term agri-environment schemes. Pages 33-52 in D. Ansell, F. Gibson, and D. Salt, editors. Learning from agri-environment schemes in Australia: Investing in biodiversity and other ecosystem services on farms. ANU Press, The Australian National University, Canberra, Australia.

Cocklin, C., N. Mautner, and J. Dibden. 2007. Public policy, private landholders: perspectives on policy mechanisms for sustainable land management. Journal of Environmental Management 85(4):986-998. http://dx.doi.org/10.1016/j.

jenvman.2006.11.009

Cooke, B., W. T. Langford, A. Gordon, and S. A. Bekessy. 2012. Social context and the role of collaborative policy making for private land conservation. Journal of Environmental Planning and Management 55(4):469-485. http://dx.doi.org/10.1080/09640568.2011 .608549

Cooke, B., and K. Moon. 2015. Aligning 'public good' environmental stewardship with the landscape-scale: adapting MBIs for private land conservation policy. Ecological Economics 114:152-158. http://dx.doi.org/10.1016/j.ecolecon.2015.03.027

Cumming, T. L. 2007. Conservation incentives for private commercial farmers in the Thicket Biome, Eastern Cape, South Africa. Thesis. Rhodes University, Grahamstown, South Africa.

Cumming, T. L., A. Driver, P. Pillay, G. Martindale, K. Purnell, K. McCann, and K. Maree. 2015. The business case for biodiversity stewardship. A report produced for the Department of Environmental Affairs. South African National Biodiversity Institute (SANBI), Pretoria, South Africa.

De Young, R. 2000. New ways to promote proenvironmental behavior: expanding and evaluating motives for environmentally responsible behavior. Journal of Social Issues 56(3):509-526. http://dx.doi.org/10.1111/0022-4537.00181

Dillman, D. A., J. Smyth, and L. M. Christian. 2009. Internet, mail, mixed-mode surveys the tailored design method. Third edition. John Wiley and Sons, Hoboken, New Jersey, USA.

Elmendorf, C. S. 2003. Ideas, incentives, gifts, and governance: toward conservation stewardship of private land, in cultural and psychological perspective. University of Illinois Law Review 2003 (2):423-505.

Ernst, T., and G. N. Wallace 2008. Characteristics, motivations, and management actions of landowners engaged in private land conservation in Larimer County Colorado. Natural Areas Journal 28(2):109-120. http://dx.doi.org/10.3375/0885-8608(2008)28[109: cmamao]2.0.co;2

Farrier, D. 1995. Conserving biodiversity on private land: incentives for management or compensation for lost expectations. Harvard Environmental Law Review 19:303-405.

George, A. L., and A. Bennett. 2005. Case studies and theory development in the social sciences. MIT Press, Cambridge, Massachusetts, USA.
Gill, N., P. Klepeis, and L. Chisholm. 2010. Stewardship among lifestyle oriented rural landowners. Journal of Environmental Planning and Management 53(3):317-334. http://dx.doi. org/10.1080/09640561003612890

Greiner, R., and D. Gregg. 2011. Farmers' intrinsic motivations, barriers to the adoption of conservation practices and effectiveness of policy instruments: empirical evidence from northern Australia. Land Use Policy 28(1):257-265. http://dx.doi. org/10.1016/j.landusepol.2010.06.006

Gunningham, N., and M. D. Young. 1997. Toward optimal environmental policy: the case of biodiversity conservation. Ecology Law Quarterly 24:243.

Harrington, C., R. Lane, and D. Mercer. 2006. Learning conservation: the role of conservation covenants in landscape redesign at Project Hindmarsh, Victoria. Australian Geographer 37(2):187-209. http://dx.doi.org/10.1080/00049180600672342

Higgins, V., J. Dibden, and C. Cocklin. 2012. Market instruments and the neoliberalisation of land management in rural Australia. Geoforum 43(3):377-386. http://dx.doi.org/10.1016/j. geoforum.2010.10.002

Higgins, V., J. Dibden, C. Potter, K. Moon, and C. Cocklin. 2014. Payments for ecosystem services, neoliberalisation, and the hybrid governance of land management in Australia. Journal of Rural Studies 36:463-474. http://dx.doi.org/10.1016/j.jrurstud.2014.10.003

Kay, G., D. Florance, J. Wood, and D. Lindenmayer. 2013. Environmental stewardship box gum grassy woodland monitoring project final monitoring report. Australian National University, Canberra, Australia.

Kitchin, R., and N. J. Tate. 2000. Conducting research in human geography: theory, methodology and practice. BenjaminCummings, San Francisco, California, USA.

Knight, A. T., R. M. Cowling, M. Difford, and B. M. Campbell. 2010. Mapping human and social dimensions of conservation opportunity for the scheduling of conservation action on private land. Conservation Biology 24(5):1348-1358. http://dx.doi. org/10.1111/j.1523-1739.2010.01494.X

Lai, P.-H., and U. P. Kreuter. 2012. Examining the direct and indirect effects of environmental change and place attachment on land management decisions in the Hill Country of Texas, USA. Landscape and Urban Planning 104(3-4):320-328. http://dx.doi. org/10.1016/j.landurbplan.2011.11.007

Leopold, A. 1949. A Sand County almanac, and sketches here and there. Oxford University Press, New York, New York, USA.

Li, W., and Y. Li. 2012. Managing rangeland as a complex system: how government interventions decouple social systems from ecological systems. Ecology and Society 17(1):9. http://dx.doi. org/10.5751/es-04531-170109

Mendham, E., A. Curtis, and J. Millar. 2012. The natural resource management implications of rural property turnover. Ecology and Society 17(4):5. http://dx.doi.org/10.5751/es-05071-170405

Moon, K., and C. Cocklin. 2011. Participation in biodiversity conservation: motivations and barriers of Australian landholders. Journal of Rural Studies 27(3):331-342. http://dx.doi.org/10.1016/ j.jrurstud.2011.04.001 
Morrisette, P. M., 2001. Conservation easements and the public good: preserving the environment on private lands. Natural Resources Journal 41(2):373-426.

Muradian, R., M. Arsel, L. Pellegrini, F. Adaman, B. Aguilar, B. Agarwal, E. Corbera, D. Ezzine de Blas, J. Farley, G. Froger, et al. 2013. Payments for ecosystem services and the fatal attraction of win-win solutions. Conservation Letters 6(4):274-279. http:// dx.doi.org/10.1111/j.1755-263x.2012.00309.x

Naidoo, R., A. Balmford, P. J. Ferraro, S. Polasky, T. H. Ricketts, and M. Rouget. 2006. Integrating economic costs into conservation planning. Trends in Ecology \& Evolution 21 (12):681-687. http://dx.doi.org/10.1016/j.tree.2006.10.003

Pannell, D. J. 2008. Public benefits, private benefits, and policy mechanism choice for land-use change for environmental benefits. Land Economics 84(2):225-240. http://dx.doi.org/10.3368/ $\underline{\text { le.84.2.225 }}$

Pannell, D. J., and R. Wilkinson. 2009. Policy mechanism choice for environmental management by non-commercial "lifestyle" rural landholders. Ecological Economics 68(10):2679-2687. http:// dx.doi.org/10.1016/j.ecolecon.2009.05.003

Pasquini, L., R. M. Cowling, C. Twyman, and J. Wainwright. 2010. Devising appropriate policies and instruments in support of private conservation areas: lessons learned from the Klein Karoo, South Africa. Conservation Biology 24(2):470-478. http:// dx.doi.org/10.1111/j.1523-1739.2009.01344.X

Race, D., and A. Curtis. 2013. Reflections on the effectiveness of market-based instruments to secure long-term environmental gains in southeast Australia: understanding landholders' experiences. Society \& Natural Resources 26(9):1050-1065. http:// dx.doi.org/10.1080/08941920.2013.779338

Reimer, A. P., A. W. Thompson, and L. S. Prokopy. 2012. The multi-dimensional nature of environmental attitudes among farmers in Indiana: implications for conservation adoption. Agriculture and Human Values 29(1):29-40. http://dx.doi. org/10.1007/s10460-011-9308-Z

Riley, M. 2006. Reconsidering conceptualisations of farm conservation activity: the case of conserving hay meadows. Journal of Rural Studies 22(3):337-353. http://dx.doi.org/10.1016/ j.jrurstud.2005.10.005

Rissman, A. R. 2011. Evaluating conservation effectiveness and adaptation in dynamic landscapes. Law \& Contemporary Problems 74:145.

Robertson, M. M. 2004. The neoliberalization of ecosystem services: wetland mitigation banking and problems in environmental governance. Geoforum 35(3):361-373. http://dx. doi.org/10.1016/j.geoforum.2003.06.002

Robins, L., and P. Kanowski. 2011. 'Crying for our Country': eight ways in which 'Caring for our Country' has undermined Australia's regional model for natural resource management. Australasian Journal of Environmental Management 18(2):88-108. http://dx.doi.org/10.1080/14486563.2011.566158

Rode, J., E. Gómez-Baggethun, and T. Krause. 2015. Motivation crowding by economic incentives in conservation policy: a review of the empirical evidence. Ecological Economics 117:270-282. http://dx.doi.org/10.1016/j.ecolecon.2014.11.019
Ryan, R. L., R. Kaplan, and R. E. Grese. 2001. Predicting volunteer commitment in environmental stewardship programmes. Journal of Environmental Planning and Management 44 (5):629-648. http://dx.doi.org/10.1080/09640560120079948

Saldaña, J. 2009. The coding manual for qualitative researchers. SAGE, Thousand Oaks, California, USA.

Selinske, M. J., J. Coetzee, K. Purnell, and A. T. Knight. 2015. Understanding the motivations, satisfaction, and retention of landowners in private land conservation programs. Conservation Letters 8(4):282-289. http://dx.doi.org/10.1111/conl.12154

Sorice, M. G., and C. J. Donlan. 2015. A human-centered framework for innovation in conservation incentive programs. Ambio 44(8):788-792. http://dx.doi.org/10.1007/s13280-015-0650$\underline{\mathrm{Z}}$

Sorice, M. G., C. O. Oh, T. Gartner, M. Snieckus, R. Johnson, and C. J. Donlan. 2013. Increasing participation in incentive programs for biodiversity conservation. Ecological Applications 23(5):1146-1155. http://dx.doi.org/10.1890/12-1878.1

Stake, R. E. 1995. The art of case study research. SAGE, Thousand Oaks, California, USA.

Stern, S. 2006. Encouraging conservation on private lands: a behavioral analysis of financial incentives. Arizona Law Review 48:541-583.

Stirling, A. 2010. Keep it complex. Nature 468:1029-1031. http:// dx.doi.org/10.1038/4681029a

Strang, V. 2010. Mapping histories: cultural landscapes and walkabout methods. Pages 132-156 in I. Vaccaro, A. Smith, and S. Aswani, editors. Environmental social science: methods and research design. Cambridge University Press, Cambridge, UK. http://dx.doi.org/10.1017/cbo9780511760242.009

Stroman, D., and U. P. Kreuter. 2015. Factors influencing land management practices on conservation easement protected landscapes. Society \& Natural Resources 28(8):891-907. http://dx. doi.org/10.1080/08941920.2015.1024365

Swart, J. A. A., P. J. Ferraro, and A. Kiss. 2003. Will direct payments help biodiversity? Science 299(5615):1981-1982. http:// dx.doi.org/10.1126/science.299.5615.1981b

Trigger, D. S., Y. Toussaint, and J. Mulcock. 2010. Ecological restoration in Australia: environmental discourses, landscape ideals, and the significance of human agency. Society \& Natural Resources 23(11):1060-1074. http://dx.doi.org/10.1080/08941920903232902

van Putten, I. E., S. M. Jennings, J. J. Louviere, and L. B. Burgess, 2011. Tasmanian landowner preferences for conservation incentive programs: a latent class approach. Journal of Environmental Management 92(10):2647-2656. http://dx.doi. org/10.1016/i.jenvman.2011.06.002

Whitten, S. M., A. Reeson, J. Windle, and J. Rolfe. 2013. Designing conservation tenders to support landholder participation: a framework and case study assessment. Ecosystem Services 6:82-92. http://dx.doi.org/10.1016/j.ecoser.2012.11.001

Wilson, G. A., and K. Hart. 2001. Farmer participation in agrienvironmental schemes: towards conservation-oriented thinking? Sociologia Ruralis 41(2):254-274. http://dx.doi.org/10.1111/1467-9523.00181 
Wondolleck, J. M., and S. L. Yaffee. 2000. Making collaboration work: lessons from innovation in natural resource management. Island Press, Washington, D.C., USA.

Worrell, R., and M. C. Appleby. 2000. Stewardship of natural resources: definition, ethical and practical aspects. Journal of Agricultural and Environmental Ethics 12(3):263-277. http://dx. doi.org/10.1023/A:1009534214698

Young, M. D., and N. Gunningham. 1996. Mixing instruments and institutional arrangements for optimal biodiversity conservation. Pages 141-165 in OECD International Conference on Incentive Measures for Biodiversity Conservation and Sustainable Use. Cairns, Australia.

Young, M. D., N. Gunningham, J. Elix, J. Lambert, B. Howard, P. Grabosky, E. McCrone. 1996. Reimbursing the future: an evaluation of motivational voluntary, price-based, property-right, and regulatory incentives for the Conservation of Biodiversity. Parts 1 and 2. Biodiversity Series, Paper No. 9. Department of the Environment, Sport and Territories, Canberra, Australia. 